\title{
Realistic vs Romantic: the Imagistic World of Post-War English Literature
}

\author{
María Antonia Álvarez Calleja \\ UNED
}

\begin{abstract}
The short story is the genre which has come closest to representing the most poetic aspects of post-Second World War English literature, not only for its linguistic and stylistic concentration, but also for its imagistic world, in which the realistic contrasts with the romantic. Nevertheless, there is a transference from the classic literary images to a modern alternative.

On the other hand, since 1945 writers have been preoccupied with the quest for self-a search for identity, an effort on the part of the heroes and heroines to understand and define who or what they are. In fact, the term identity plays a central role in virtually every judgment or opinion of the post-war literary scene.
\end{abstract}

The general trends and directions of post-Second World War English literature have been distinguished by their "imagistic methods and symbolic potential," as Malcolm Bradbury affirms in his Introduction to The Penguin Book of Modern British Short Stories, since contemporary writers have explored the "long-standing tradition of realistic narrative and the notion of it as an art of language, of experimental form and symbol; a notion that has often led in the direction of the strange, the fantastic, the grotesque, the surreal and the myth." (13)

Since 1945 English literature has created a vast, imagistic world, which can be illustrated with many examples, e.g. Ted Hughes's deep human realities in his visions of animals; Fay Weldon's alternatives to the classic concept of Englishness; the manipulation 
of voice introduced by Philip Larkin in his poems to present authorial experience; the elevation of individual suffering achieved by Beryl Bainbridge through her ironic mode; Muriel Spark and Elizabeth Bowen's images of romantic reality, which derive their power from a claustrophobic atmosphere; Seamus Heaney and Tony Harrison's images of self in their memories of infancy and early childhood, as their re-possession of poetic talent, etc.

In order to find the methods used to create all this highly artistic world, we must begin by analysing some post-Second World War English short stories and poems.

\section{Human images from Ted Hughes's visions of animals}

In the short story "The Rain Horse", ${ }^{1}$ Hughes discovers deep human realities from his visions of animals where man and horse share indistinguishably the same life-force:

As he turned, something moved in his eye-corner. All his senses started alert. He stopped. Over to his right a thin, black horse was moving across the ploughland towards the hill, its head down, neck stretched out. It seemed to be running on its toes like a cat, like a dog up to no good. $(\mathrm{RH}, 127)$

A key point in the story is the neurotic behaviour of the main character: he has returned home after a twelve-year absence and the landscape where he was born only means boredom and impatience to him. He is angry because of the mud produced by the heavy rain:

A wave of anger went over him: anger against himself for blundering into this mud-trap and anger against the land that made him feel so outcast, so old and stiff and stupid. He wanted nothing but to get away from it as quickly as possible. (RH,127)

He also feels discomfort at the appearance of the horse "like a nightmarish leopard" ( $\mathrm{RH}, 127)$. He is not afraid at first, but enjoying his walk. In spite of getting wet, "as long as it lasted he was suspended from life and time" $(\mathrm{RH}, 128)$. He only thinks that "horses wander about the countryside often enough"(RH,128), but he is convinced that the animal is only "watching him, perfectly still"(RH,129). However, suddenly the mood of the story changes, and the horse becomes malevolent when the man resolves not to deal with the animal's watchful presence, that is, when he decides to repress his emotions and banish the horse from his consciousness, which, according to Leonard M. Scigaj, symbolizes "the repressed libidinal energies in the man's own psyche, a favourite technique of German expressionistic drama." (54):

If it wanted to share the wood with him, let it. If it wanted to stare at him, let it. He was nestling firmly into these resolutions when the ground shook and he heard the crash of the heavy body coming down the wood, like lightning his legs bounded him upright and about face. The horse was almost on top of him, its head stretching forwards, ears flattened and lips lifted back from the long yellow teeth. He got one snapshot glimpse of the red-veined eyeball as he flung himself backwards. (RH,129) 
As Gifford \& Roberts affirm, this distinctly masculine energy that characterizes Ted Hughes's poetic prose derives from a "worship of Nature" (25):

He got up furious. Knocking the dirt and leaves from his suit as well as he could he looked around for a weapon. The horse was evidently mad, had an abcess on its brain or something of the sort. Or maybe it was just spiteful. Rain sometimes puts creatures into queer states. $(\mathrm{RH}, 129)$

In fact, this almost human image of the rearing horse, together with the sound effects ("its whinnying snort and the spattering whack of its hooves" [RH,131]) creates the intensity of Hughes's imagistic world, as also happens in his poem "Wodwo" - the final poem, which gives the title Wodwo to the volume-although the images are different, since his objective was to catch the spirit of a half-man, half-animal, who still belongs to nature and whose freedom is a mystery to himself; thus his incessant questioning:

What am I? Nosing here, turning leaves over

Following a faint stain on the air to the river's edge

I enter water. $(\mathrm{W}, 147)$

The wodwo may be seen as a humble man (the poet) seeking experience. Keith Sagar suggests that because of "the absence of clear signs and certainties, dangers and horrors, beauties and miracles he is alert in all his faculties and moves forward to confront the world." (99). What Hughes presents is a creature unaware of what he is able to do, without any definite clue as to what he really is, where he has come from, or what he is doing:

What am I to split

The glassy grain of water looking upward I see the bed

Of the river above me upside down very clear

What am I doing here in mid-air? (W,147)

These questions, which strike us in the poem, are "a curious but vaguely sorrowful inquiring search for a proper basis on which to reorient oneself" (Hirschberg 66). The wodwo's perceptions are very much those we might expect of an animal, because when he moves, he perceives the world moving towards himself in a totally naive way, and if he stands still he perceives everything stopping to watch him:

Do these weeds

know me and name me to each other have they seen me before, do I fit in their world? $(\mathrm{W}, 147)$

At the end of the poem, the wodwo says, rather resignedly:

I suppose I am the exact centre

but there's all this what is it roots 
roots roots roots and here's the water

again very queer but I'll go on looking (W,148)

The way in which Hughes presents his last verse -after beginning within at least some of the familiar conventions of syntax and puctuation, the poem proceeds by discarding even commas and full stops or capital letters-means that the process of asking questions and finding answers will go on and on, until Hughes's vision of the animal permits us to see the wodwo's human image as narrator, asking a series of childlike questions.

This almost human image contrasts with "Pibroch", an ultimate expression of Hughes's vision of the world, where he tries to describe a landscape where organic life is almost totally absent. In this poem, the metaphors permit us to see the landscape as an image of the human condition, imprisoned within itself and going nowhere:

Stone likewise. A pebble is imprisoned.

Like nothing in the Universe.

Created for black sleep. Or growing

Conscious of the sun's red spot occasionally,

Then dreaming it is the foetus of God. $(\mathbf{P}, 151)$

Here Hughes creates an image of the tree like a crazy old woman, hanging on to barren life tenaciously, and the relation between woman and nature, projected into language by human images, produces in the reader a shock of vitality instead of violence:

Drinking the sea and eating the rock

a tree struggles to make leaves-

An old woman fallen from space

Unprepared for these conditions.

She hangs on, because her mind's gone completely. $(\mathrm{P}, 151)$

\section{Fay Weldon's new alternatives to the classic image of Englishness}

In post-Second World War literature, the image of Englishness was substantially transformed, but, as Brian Doyle has suggested, "the enhancement of English and Englishness, which was one of its major products, drew on the raw materials provided by the scholarly work of the middle decades of the nineteenth century." (21)

When discussing the concept of Englishness, the focus is placed by many literary critics on national identity. M. Spiering states that in post-war English literary and cultural criticism "the term identity plays a central role" (4-5), considering national identity as an image that "carries meaning in the sense that it abides in feelings and convictions." (8)

Post-war short stories are preoccupied with the quests for self; they are searches for identity, efforts on the part of the heroes to understand and define who or what they are. A good example is Fay Weldon's heroine and narrator in "Weekend", which presents a clearly feminist point of view. She cannot stand either her duties as a housewife or her 
work in an office: "So Martha perched uneasily on the steps and had a glass of cider, and wondered how, if lunch was going to be late, she would get cleared up." (We,319) Thus, she tries to find a way to maintain her post as a market researcher in an advertising agency while she attends her strong husband's demands:

Martin can't bear bad temper. Martin likes slim ladies. Diet. Martin rather likes his secretary. Diet. Martin admires slim legs and big bosoms. How to achieve them both? Impossible. But try, oh try, to be what you ought to be, not what you are. Inside and out. (We,312)

The notions of niceness and tenderness is a key point in Fay Weldon's "Weekend," since, in order to be successful, Martha has to be a kind creature:

'Don't fret, Martha. I'll do it.' 'Don't fret.' Martha clearly hadn't been smiling enough. She was in danger, Martin implied, of ruining everyone's weekend. Martin frowned at Martha: he thought the appearance of martyrdom in the face of guests to be an unforgivable offence. (We,323)

Among the several characteristics which can be labelled as Englishness -amateurism, class, countryside, democracy, eccentricity- another typical element concerning Englishness is to express some value judgements with a sense of humour: the typical English humour or, at least, a twist of irony. As Leavis affirms, "this stereotype, after all, finds a natural and wide field in jokes and witticisms" (8), as we can see in this short story:

'Martha, you can't not want roses! What kind of person am I married to? An anti-rose personality?' (We,304)

"Weekend" is a book of denunciation and protest, by women who have to perform in life their double role as wives and outdoor-workers. And in order to convey her message to the reader, the author presents two different kinds of women: the self-centred woman and the self-sacrificing woman. Katie is a typical example of the first, a superficial woman who has become Colin's new young wife:

Katie was languid, beautiful and elegant. She drawled when she spoke. Her hands were expressive: her feet were like a female. She had no children. (We,315)

She has succeeded Janet - Colin's first wife. Janet and Marta represent the second type, the self-sacrificing woman:

Janet was rather like Martha, quieter and duller than her husband. A nag and a drag, Martin rather thought, and said, and of course she'd let herself go, everyone agreed. No one exactly excused Colin for walking out, but you could see the temptation. (We,315) 
For Q.D. Leavis, post-Second World War novelists seem to have abdicated from moral responsibility. This can be seen, she claims, when comparing the output of women novelists of the present and recent past: “They seem to be universally determined, forgoing their heritage as English novelists, to belong to an international women writer's movement, a movement characterized by a jargon that is the opposite of wisdom or maturity. Judging from a current publisher's catalogue, women novelists are now invariably committed to the search for identity, sexual fulfilment, a need for connection and commitment and a search for her primitive self, with demonstrating love-hate relationships and the varieties of sexuality open to women." (324-5) Leavis asks herself if the England that bore the classical English novel has gone forever, since "rescuing the individual from the family is no longer a concern, the problem is to find any stable family life for the individual to develop full humanity in." (5) This is what Weldon's heroine faithfully tries to achieve through her constant effort:

Then supper - pork chops in sweet and sour sauce ('Pork is such a dull meat if you don't cook it properly': Martin), green salad from the garden, or such green salad as the rabbits had left ('Martha, did you really net them properly? Be honest now!': Martin) and sauté potatoes. Mash is so stodgy and ordinary, and instant mash unthinkable. (We,314)

...if breakfast for seven is to be manageable the sink must be cleared of dishes. A tricky meal, breakfast. Especially if bacon, eggs, and tomatoes must all be cooked in separate pans. ('Separate pans mean separate flavours!': Martin) (We,316)

But, as Leavis affirms, "though this may account for, it does not excuse the stream of novels with pretensions to being more than commercial enterprises, which admire the brutally selfish, and anti-social man or, like the new women novelists, glorify the untrammelled female egotist." (324-5) In "Weekend," Fay Weldon presents ironically this type of selfish woman to ridicule her, contrasting her characteristics with the virtues of the heroine:

'It does one no good to be materialistic,' Katie confided, 'I have nothing. No home no family, no ties, no possessions. Look at me! Only me and a suitcase of clothes.' But Katie seemed highly satisfied with the me and the clothes were stupendous. Katie drank a great deal and became funny. Everybody laughed, including Martha. Katie had been married twice. Martha marvelled at how someone could arrive in their mid-thirties with nothing at all to their name, neither husband, nor children, nor property and not mind. Mind you, Martha could see the power of such helplessness. If Colin was all Katie had in the world, how could Colin abandon her. And to what? Where would she go? How would she live? Oh, clever Katie. (We,318)

An alternative for another classical image of Englishness in the context of postSecond World War English literature is ruralness. As a reminiscence of rural life, English people keep their gardens which cannot be separated from the idea of English family life. And in the gardens, as Fay Weldom implies, the most famous element are English roses: 
Real roses round the door.

Roses. Prune, weed, spray, feed, pick. Avoid thorns. One of Martin's few harsh words. (We,313)

"Following the country-city contrast," as John H. Jonston states, "vice and folly are identical as intrinsically urban ills" (190), and M. Spiercing adds that "the vision of England as an essentially rural community crystallized in the late nineteenth century and has since then remained one of the central images of Englishness" (179), which is also present in "Weekend":

Green grass. Oh, God, grass. Grass must be mown. Restful lawns, daisies bobbing, buttercups glowing. Roses and grass... (We,313)

It is important to understand that the rural image conveys a positive quality, since Englishness equals humaneness. The idea that the English self is more humane than the other's has probably always played a part in shaping the image of national identity. For Spiering, "though it seems likely that ruralism is not an exclusively English preserve, the idea that the national self is rooted in the country, and should be protected from the withering forces of internationalism and federalism, appears particularly prevalent in postwar English. Both features are but aspects of the English self-image" (179), although this image has been changed to a considerable extent, its original meaning being denied and its great spiritual influence forgotten.

\section{Authorial image through Philip Larkin's manipulation of voice}

One of Philip Larkin's ways of writing a poem is to introduce the idea that a passive observer (the poet) sees more clearly what is happening than even the omniscient narrator. This is the case of "Mr Bleaney" , one of his best poems, where -as George Hartley affirms - this passive observer sees "the big illusions in life, and perhaps therefore has a greater sensitivity to the reality of pain and suffering that underlies many of Larkin's poems" (88). Salem K. Hassan adds that "by capturing moments of dissatisfaction with life," Larkin introduces "a remarkable vision of that state when we are far away from the fulfilment of our wishes." (44)

In March 1955, Larkin wrote to Eva Larkin, his mother, that he was living in a noisy house, where the landlady was "extremely kind and thoughtful," the food "not bad," but his room was "too small" and prevented him "from, thinking and scribbling in the evening." Thus, in the poem that he managed to finish soon after arriving there, originally "Mr Gridley," according to Motion (247), he depicts the room in rather sad words:

Flowered curtains, thin and frayed,

Fall to within five inches of the sill, Whose window shows a strip of building land, Tussocky, littered. (MB,121) 
This poem shows the attitude of the poet when he arrived at his new residence. We can notice the precision of the list of things describing the life of the previous lodger by speculating on his belongings, the surroundings of the bedroom and a few remarks the landlady makes about him:

\section{'Mr Bleaney took}

My bit of garden properly in hand,'

Bed, upright chair, sixty-watt bulb, no hook... (MB,121-2)

The title "Mr Bleaney" announces what the poem is all about. In fact, as Michael Riffaterre states, "One of the functions of the title is to help the reader to discover a clue to the poem; a key to unlock its meaning, or to inform the reader and facilitate access to the text by stating its subject, its genre, or its code. Thus the title functions as a sign hinting at a hidden meaning, or a meaning reserved for initiates, or a second meaning in addition to the surface one" (100). David Timms, in his interesting discussion of the relevance of the title to the meaning of the whole poem, adds that the title shows how mean life can be for Mr Bleaney, since the name combines the notions bleak and mean, and ends in the diminutive -ey.

Nevertheless, what is important to observe is that when Larkin wrote this poem in May 1955, he introduced what can be considered one of his great stylistic discoveries, the manipulation of voice, since the speaker is not "the neutral, authorial voice presenting an experience or making a statement about it" (Tolley 87). On the contrary, the poet manipulates the voice of the narrator and he presents with compelling pity Mr Bleaney's loneliness and despair, making us feel the fear that this description may also apply to the writer and even to the reader:

Telling himself that this was home, and grinned,

And shivered, without shaking off the dread. (MB,122)

Thus, the speaker -and also the reader- had been led to identify themselves with $\mathrm{Mr}$ Bleaney through an important element in Philip Larkin's way of writing, that tactic of comparison which enriches most of his poetry. In this way, the speaker "makes an argument for sameness between himself and his double, which actually stresses the difference between them" (Rossen 37):

So it happens that I lie

Where Mr Bleaney lay, and stub my fags

On the same saucer-souvenir, and try

Stuffing my ears with cotton-wool (MB,122)

But although the contrast between the two men is heavily stressed and they are presented as two distinct figures, they are none the less identified with each other because they are both measured by the tiny rented room. Nevertheless, the differences between the men are quite clearly delineated: Mr Bleaney seems to have been a sort of extrovert, whom the landlady liked and whose voice continues to chatter in the form of "The jabbering set 
he egged her on to buy" (MB,122). On the contrary, the poet is an introvert -his only verbal comment is "I'll take it"- and his needs are different from those of Mr Bleaney:

Bed, upright chair, sixty-watt bulb, no hook

Behind the door, no room for books or bags- $(\mathrm{MB}, 122)$

Moreover, Larkin uses other elements to define the main character: the most important point is the emphasis in the poem on uncertainty rather than on certainty, since, in spite of all his knowledge about the first guest, the departed Mr Bleaney remains a mystery. It is impossible to know what he thought, and Janice Rossen even sees in the poem "a strange, lucid quality of a murder mystery or spy novel, where the investigator tries to reconstruct a dead or departed man's life and thoughts." For her, "the dialectic inherent in the poem keeps broadening out into certainty-Bleaney seems to have been such a simple fellow that we feel we have him trapped-and then collapsing into uncertainty." (37) In fact, the very structure of a poem like "Mr Bleaney," Christopher Ricks affirms, "turns upon the decision as to the precise degree of stress and precisely where to lay it" (126), because when the speaker takes Mr Bleaney's place, the rest of the poem is very simple:

I know his habits - what time he came down,

His preference for sauce to gravy, why

He kept on plugging at the four aways-

Likewise their yearly frame: the Friton folk

Who put him up for summer holidays,

And Christmas at his sister's house in Stoke. (MB,122)

Without the contrast between these sentences and the last two stanzas, the poem would not exist:

But if he stood and watched the frigid wind

Tousling the clouds, lay on the fusty bed

Telling himself that this was home, and grinned,

And shivered, without shaking off the dread

That how we live measures our own nature,

And at his age having no more to show

Than one hired box should make him pretty sure

He warranted no better, I don't know. (MB,122)

With the last clause I don't know the poet seems to ask himself whether he was just like Mr Bleaney. This leads Janice Rossen to suggest that the poet himself "feels undervalued," since this uncertainty "serves to reinforce the pessimism inherent in the poem." (138) 
How empty and meaningless Bleaney's life is can be seen in the first five stanzas - which are an expansion of the title- through the details of the room: bed, upright chair, sixty-watt bulb and no room for books or bags. This featureless room which has been $\mathrm{Mr}$ Bleaney's home, and the dullness of his life, show him as an indifferent person. For Veronica Forrest-Thomson, "the opening stanzas of the poem refer us to a known world and invite us to explore the associations of the real in an operational expansion." (58) Certainly, they give a faithful picture of Mr Bleaney's life, and show the poet's remarkable ability to depict reality, which Philip Hobsbaum calls his real genius - his capacity for "setting down reality as it is, not as other people have held it to be." (22)

There are several enjambments throughout the poem which create a sense of continuity. Geoffrey Leech considers them necessary to the "descriptive process" established by Larkin, since they invite to the "meditative state"; the process of meditation is intensified "by the conflict it creates between the metrical system which requires a pause and the grammatical system which resists such a pause." (24) There is also a vivid use of colloquialism and a great economy in the language used by Larkin to describe $\mathrm{Mr}$ Bleaney's belongings; poor as they are, they serve as witnesses to his shabby personal life, and show how empty and meaningless it is, as well as sad. However, as Salem Hassan suggests, "Mr Bleaney's existence, without meaning as it is, becomes a problem to which he finds no solution other than nihilism" (45). In fact, Mr Bleaney's inability to face the problems of his own life may be the result of his failure to participate in an effective way, performing only the role of an observer instead of a participant, since he spends his summer holidays at Frinton and Christmas at Stoke, two places significantly chosen for their dullness. These activities make Hassan consider Mr Bleaney as "helplessly victimised by time." He explains that if "his present has been abandoned, as it turns out to be a heavy load that burdens his shoulders," consequently "the past cannot be relived in the present nor can the future be looked upon as a harbinger of a dawn of happier days. This abolition of the present is a barrier holding him back from the promise of what lies ahead, the future." (45) It is "the lack of the knowledge of time" which is the key point in $\mathrm{Mr}$ Bleaney's case:

But if he stood and watched the frigid wind

Tousling the cloud... (MB,122)

The strength of the poem lies in the contrast established between these two stanzas and the first part of the poem. As Hassan affirms: "the poet's knowledge of time is heightened by a remarkable contrast between the passive interior - $\mathrm{Mr}$ Bleaney's featureless room and the sort of life it symbolises - and the hostile exterior, the cold wind tousling the clouds." (45) Nevertheless it does not mean that the poet is going to follow the same kind of life as Mr Bleaney, even though he has agreed to live in the same room:

So it happens that I lie

Where Mr Bleaney lay, and stab my fags

On the same saucer-souvenir... (MB,122) 
In fact, there is a great preoccupation in this poem with the individual life, related to a concern with personal identity, and the conclusion is not clear since Larkin does not want to venture a judgement. The poet even makes the main clause come at the end, perhaps to make us unclear as possible his position; in fact, perhaps it shows the tortuousness of his thought: He warranted no better, I don't know (p.122). Nevertheless, it does not matter whether Larkin's conclusion is by no means clear. In "Mr Bleaney" there seems to be a conscious, clear control of tone, however complex the interplay of attitudes, because of the use of natural language for poetry:

'This was Mr Bleaney's room. He stayed

The whole time he was at the Bodies, till

They moved him.' (MB,121)

The use of direct speech from the opening of the poem, by a person we do not know yet, seems to present the everyday world to us as his relationship to experience, and the revelation it brings with the appearance of naturalness indicates that the poet is an intellectual, since he looks for bookshelves, and Bleaney is not. Thus, contrary to $\mathrm{Mr}$ Bleaney, whose past has no meaning and whose present is a wearisome burden, the poet transmits his hopeful thought using a new structural characteristic: the manipulation of voice, where the speaker is not the neutral observer, but the authorial image or Larkin's voice and experience making his own positive statements about it.

\section{The image of existence underlying Beryl Bainbridge's ironic mode}

Short stories are the genre which have come closest to representing the most poetic aspect of Bainbridge's craft, through their linguistic and stylistic concentration, imagistic methods and symbolic potential. A good example is "Clap Hands, Here Comes Charlie", full of a cruel black humour. Its structure and sequence of actions follow the key points of Peter Pan, whose performance in the theatre is the frame of the story .

There are affinities between Beryl Bainbridge's fictional constructions to convey the ironic mode underlying her short story, and Michail Bakhtin's theory on the burlesque and carnivalistic, developed in The Dialogic Imagination (1982), and later in Rabelais and his World (1984):

The principle of laughter and the carnival spirit on which the grotesque is based destroys this limited seriousness and all pretense of an extratemporal meaning and unconditional value of necessity. It frees human consciousness, thought, and imagination for new potentialities. For this reason great changes, even in the field of science, are always preceded by a certain carnival consciousness that prepares the way. (49)

Bainbridge uses the technique of bringing out connections between things kept apart or separating things traditionally connected, which is also important in Bakhtin's carnivalistic laughter and its victory over fear: 
The people play with terror and laugh at it; the awesome becomes a comic monster. Neither can this grotesque image be understood if oversimplified and interpreted in the spirit of abstract rationalism. It is impossible to determine where the defeat of fear will end and where joyous recreation will begin. (91)

In Bakhtin's theory the grotesque is paradoxical, and this paradox -the combination of the grotesque and laughter- makes carnivalism very radical because through victory over fear, laughter reveals the mysteries of power:

It liberates from the fear that developed in man thousands of years ago: fear of the sacred, of prohibitions, of the past, of power. It unveils the material bodily principle in its true meaning. Laughter opened men's eyes on that which is new, on the future... Laughter showed the world anew in its gayest and most sober aspects. Its external privileges are intimately linked with interior forces; they are a recognition of the rights of those forces. This is why laughter could never become an instrument to oppress and blind the people. It always remained a free weapon in their hands. (94)

In fact, laughter is directed against all boundaries of hypocrisy and adulation, and so it liberates a human being from any internal censor. In "Claps Hands, Here Comes Charlie," hypocrisy appears from the beginning of the story, mixed with an ironic mode:

Two weeks before Christmas, Angela Bisson gave Mrs Henderson six tickets for the theatre. Mrs Henderson was Angela Bisson's cleaning lady.

'I wanted to avoid giving you money,' Angela Bisson told her. 'Anybody can give money. Somehow the whole process is so degrading...taking it...giving it. They're reopening the Empire Theatre for a limited season. I wanted to give you a treat. Something you'll always remember.'

Mrs Henderson said, 'Thank you very much.' She had never, when accepting money, felt degraded. $(\mathrm{CH}, 334)$

The fictional world of Beryl Bainbridge can be described in terms of negative categories -imperfection, frustration, disorientation- in her typically sarcastic way of writing:

Her husband, Charles Henderson, asked her how much Angela Bisson had tipped her for Christmas.

Mrs Henderson said not much. 'In fact,' she admitted, 'nothing at all. Not in your actual pounds, shillings and pence. We've got tickets for the theatre instead.'

'What a discerning woman,' cried Charles Henderson. 'It's just what we've always needed.' (CH,334)

In terms of the action of the story, it seems that there is a conflict with culture, in this case represented by the son Alex:

'The kiddies will like it,' protested Mrs Henderson. 'It's a pantomime. They've never been to a pantomime.' 
Mrs Henderson's son, Alec, said Peter Pan wasn't a pantomime. At least not what his mother understood by the word. Of course, there was a fairy-tale element to the story, dealing as it did with Never-Never land and lost boys, but there was more to it than that. 'It's written on several levels,' he informed her. (CH,334)

Ironically, the frustrated aim of union among the members of the family leads to rebellion, the result being a displacement of the father's authority:

'I've been a lost boy all my life,' muttered Charles Henderson, but nobody heard him. 'Shut up, Charlie,' said Alec. His father hated being called Charlie. (CH,334-5)

As an image of existence, the family is not only the symbol of the imperfect condition of life as entrapment and separation, but also of humankind's distorted visions of the ideal:

He remembered the time Alec had come home half an hour late from the Clubs -the length of those minutes, the depth of that fear. It didn't matter what his feelings had been towards Alec for the last ten years. He didn't think you were supposed to feel much for grown-up children. He had loved little Alec, now a lost boy, and that was enough. $(\mathrm{CH}, 339)$

The ironic meaning of the story is a totally confused interpretation of the facts:

Something dramatic was happening on stage. Peter had woken up and was having a disjoined conversation with Tinkerbell, something to do with cough mixture and poison. Tink, you have drunk my medicine...it was poisoned and you drank it to save my life...Tink dear, are you dying? $(\mathrm{CH}, 339-40)$

Confusion and entrapment lead to demonstrations of the human capacity for good and the strength of ardent human desires:

The tiny star that was Tinkerbell began to flicker. Charles Henderson could hear somebody sobbing. He craned sideways to look down the row and was astonished to see that his grandson was wiping at his eyes with the back of his sleeve. Fancy Wayne, a lad who last year had been caught dangling a hamster on a piece of string from a window on the fourteenth floor of the flats, crying about a light going out. $(\mathrm{CH}, 340)$

Mr Henderson is suffering while all the audience enjoy the play, and the elevation of the dignity of individual suffering, as Elisabeth Wennö has suggested, is achieved because "presented without narratorial moralisation, and as unrelated to good and evil, the non-illusory exposure of shortcomings and undesirable behaviour transforms the manifest cultural question of right and wrong into an existential problem of true and false." (59) There is a perfectly logical relationship between the fictional world which is being performed on the stage and the real world: 
During Act Four Charles Henderson asked his wife for a peppermint. His indigestion was fearsome. Mrs Henderson told him to shush. She too seemed engrossed in the pantomime. Wayne was sitting bolt upright. Charles Henderson tried to concentrate. He heard some words but not others. The lost boys were going back to their Mums, that much he gathered. Somebody called Tiger Lily had come into it. And Indians were beating tom-toms. His heart was beating so loudly that it was a wonder Alec didn't fly off the handle and order him to keep quiet. $(\mathrm{CH}, 339)$

There is no solution for Mr Henderson's suffering, frustration and misfortune:

All the same, Charles Henderson was irritated. His wife's attitude, and the caustic remarks addressed to him earlier by Alec brought on another attack of indigestion. It was no use going to his bed and lying flat. He knew from experience that it wouldn't help. $(\mathrm{CH}, 335)$

But there is a suggestion that the ideal seen as collective interdependency, true integration, and collective transcendence would have generated fewer contradictions than would have arisen in a more beneficial situation:

In the old days, when they had lived in a proper house, he could have stepped out of the back door and perambulated up and down the yard for a few minutes. $(\mathrm{CH}, 335)$

Remembering the flat where the family lives now in the city makes him feel even worse: "Had there been anything so exalted as a back door in this hell-hole, going out of it certainly wouldn't improve his health." (CH,335) Bainbridge's image of existence through the complexity of perceptions of reality is thus presented in the contrast between country and city, where the city embodies all evils:

It wasn't normal, he thought, to be perpetually on a par with the clouds. People weren't meant to look out of windows and see nothing but sky, particularly if they weren't looking upwards. God knows how Moira's kiddies managed. They were stuck up in the air over Kirby. $(\mathrm{CH}, 335)$

And the country refers back to the ideal of childhood, and the young couple; obscure but full of happy remembrances:

When Moira and Alec had been little they'd played in the street-Moira on the front step fiddling with her dolly, Alec on the one roller-skate scooting in and out of the lampposts. $(\mathrm{CH}, 335)$

All these remembrances in Beryl Bainbridge's story, according to Wennö, reveal a kind of ethical irony:

Of course there was no denying that it had been nice at first to own a decent bathroom and have hot water coming out of the tap. After only a few weeks it had become 
unnecessary to scrub young Alec's neck with his toothbrush; the dirt just floated off on the towel. But there was surely more to life than a clean neck. (CH,335-36)

The final effect lies in the "complex interaction between the conscious project of recording the past by concentrating on the intersubjective relationships of certain elements, emphasizing individual choice, and the ironic transformation, emphasizing nonrational social processes as the shaping force. The ironic formula of her style serves to assert individual autonomy as well as its dependence on social context" (Wennö 177):

At the end of the yard of the terraced house in which he had once lived, there had been an outside toilet. Sitting within the evil-smelling little shed, its door swinging on broken hinges, he had sometimes glimpsed one solitary star hung motionless above the city, given perspective to his situation, his situation in the wider sense - beyond his temporary perch. He was earthbound, mortal, and a million light-years separated him from that pale diamond burning in the sky. One star was all a man needed. $(\mathrm{CH}, 336)$

The illusion of the inevitable deterministic explanation of tragedy focuses on the irrational foundation of life: "When the curtain went up, he was beginning to feel the first twinges of his indigestion coming on again" $(\mathrm{CH}, 337)$. But it is not until the end of the narrative that the full meaning of the ending is revealed, which ironically minimizes the catastrophe - the actual and cruel death of $\mathrm{Mr}$ Henderson, without anybody paying attention to his suffering:

Charles Henderson's own hands were clasped to his chest. There was a pain inside him as though somebody had slung a hook through his heart. The clapping increased in volume. The feeble Tinkerbell began to glow. She sailed trimphantly up the trunk of a painted tree. She grew so dazzling that Charles Henderson was blinded. She blazed above him in the skies of Never-Never land.

'Help me,' he said, using his last breath.

'Shut up, Charlie,' shouted Mrs Henderson, and she clapped and clapped until the palms of her hands were stinging. $(\mathrm{CH}, 340)$

\section{Elizabeth Bowens and Muriel Spark's images of romantic reality}

In the following two tales, the setting is realistic as well as romantic, and there is also realism as well as romanticism in the story.

In "Mysterious Kôr", ${ }^{7}$ Elizabeth Bowen describes the claustrophobic atmosphere of the setting, presenting London as an image of dryness where the essential being only can reside in the state of feelings:

Something more immaterial seemed to threaten, and to be keeping people at home. This day between days, this extra tax, was perhaps more than senses and nerves can bear. People stayed indoors with a fervour that could be felt: the buildings strained with battened-down human life. (MK,32) 
As the writer implicitly suggests, after the Second World War the possibilities for survival may only reside in emotional feeling, in reflecting tensions and desires:

Callie extended her sword-cold body: she tried to compose her limbs; even they quivered after Arthur's words in the dark, words to the dark. The loss of her own mysterious expectation, of her love for love, was a small thing besides the war's total of unlived lives. $(\mathrm{MK}, 44)$

Walter Allen has seen Elizabeth Bowen's work as "Henry James superimposed upon Jane Austen, in its suggested association of the subjective and objective" (192), and Allan E. Austin considers that Bowen's central concern with human feelings "must inevitably link her to the foremost emotional realist of the century, D. H. Lawrence." (201)

Bowen's fiction frequently originates with feelings arising from a particular locale rather than from a character or a story line. Her narrative occurs in well-realized settings which provide a medium where her characters move through, as can be seen in "Mysterious Kôr":

Full moonlight drenched the city and searched it. There was not a niche left to stand in. London looked like the moon's capital -shallow, cratered, extinct. It was late, but not yet midnight; now the buses had stopped, the polished roads and streets in this region sent for minutes together a ghostly unbroken reflextion up. The soaring new flats and the crouching old shops and houses looked brittle under the moon, which blazed in windows that looked its way. (MK,32)

But this sense of density of the descriptive passages can only be understood because the story occurs in wartime: "The sky, in whose glassiness floated no clouds but only opaque balloons, remained glassy-silent. The Germans no longer came by the full moon." (MK,32) Everything in the short story tries to build up a powerful sense of the exasperating nature of life in London during the war-there are no lights, only moonlight: "from the sky, presumably, you could see every slate in the roofs, every white kerb, every contour of the naked winter flower beds." (MK,32)

Nevertheless, even though the story occurs in war time, there is romanticism as well as realism, the first represented by the two girls and the second by the only man, the soldier: Arthur even changes his mind after walking with his girl through the mysterious $K o ̂ r$, which is London's image of dryness. But the two girls' romanticism is different: Kôr is for Pepita a reality which is opposed to the unreal chaos of her world, while Callie's response to life, to love and to moonlight is romantic. She fails to understand Pepita's angry reaction to her question: "Do you think Arthur's got all he wants?," and we are left to ponder whether she will discover reality, and will have satisfaction in human love, which we are sure Pepita will not.

And in "The House of the Famous Poet" - set, as it happens, in the same year as Elizabeth Bowen's "Mysterious Kôr"- Muriel Spark's characters delight in ironic bargains, paying some shillings to get an abstract funeral, which causes Velma Bourgeois 
Richmond to stress her "outrageous playfullness" (1), even about serious subjects that are important to the story, in contrast with the description of the poet's house, whose intimacy is sacred for her:

The blue cracked bathroom, the bed on the floor, the caked ink bottle, the neglected garden, and the neat rows of books - I try to gather them together in my mind whenever I am enraged by the thought that Elise and the poet were killed outright. The angels of the Resurrection will invoke the dead man and the dead women, but who will care to restore the fallen house of the famous poet if not myself? Who else will tell its story? (HFP,188)

Although the great qualities of Spark - for many critics she is the best novelist now writing in English - are mainly shown in her long novels, the short stories seem to be quite appropriate for her irony, which sometimes derives its power from the setting, as happens in "The House of the Famous Poet." At the beginning of the story, when the narrator economically describes the scene and tells us about the row of people opposite her in the train compartment - "they resembled a twelfth-century fresco" (HFP,181)- we immediately see its reversal:

There was a look of medieval unselfconsciousness about these people, all except one. This was a private soldier who was awake to a greater degree than most people are when they are not sleeping. (HFP,181)

The surreal juxtaposition is an essential part of Spark's ironic method:

'The thing is, I've got to get back to camp and I'm stuck for the fare - eight and six.' I told him I could manage it, and was finding the money when he said, putting his parcel on the floor, 'I don't want to borrow it. I wouldn't think of borrowing it. I've got something for sale.'

'What's that?' I said.

'A funeral,' said the soldier. 'I've got it here.'

This alarmed me, and I went to the window. No hearse, no coffin stood below. I saw only the avenue of trees.

The soldier smiled. 'It's an abstract funeral,' he explained, opening the parcel. (HFP,186)

One of Muriel Spark's qualities - which Ruth Whittaker compares with Doris Lessing's early work - is her "attempt to create their own defences" in her protagonists "against the sterility surrounding them." (21)

Spark makes the reader feel a certain confusion at the end, because she offers him the opportunity to share a role in the story:

When I reflect how Elise and the poet were taken in, how they calmly allowed a wellmeaning soldier to sell them the notion of a funeral, I remind myself that one day I will accept, and so will you, an abstract funeral, and make no complaints. (HFP,188) 
Had Elise and the poet perished just because they accepted the abstract funeral? Who is this soldier with this strange article to sell? One answer to these questions can be found in the interpretation of Jennifer Lynn Randisi, who thinks that "in Muriel Spark's last novels plot is another word for fate." (10) In fact, the author-narrator appears now and then through the story to give some messages to the reader; perhaps Spark's main message is that she wants us to understand the joy of the artist in taking her characters from one situation into another:

You will complain that I am withholding evidence. Indeed, you may wonder if there is any evidence at all. 'An abstract funeral,' you will say, 'is neither here nor there. It is only a notion. You cannot pack a notion into your bag. You cannot see the colour of a notion. You will insinuate that what $I$ have just told you is pure fiction. Hear me to the end. (HFP,186)

\section{Images of self in Seamus Heaney and Tony Harrison's memories of childhood}

Seamus Heaney does not write in the language of the rational materialistic world. As Nicholas McGuinn affirms, "like Ted Hughes and other poets of the post-Christian, post-Holocaust age, his concern is to discover (or rediscover) a myth which will help his people to find peace in their strife-torn society. To follow Heaney on his artistic journey, the reader needs imagination rather than reason -and must look at the world, not through the eyes of St. Patrick, but the older eyes of Oisin." (5) Being a Catholic in Northern Ireland extends far beyond the forms of the religion itself. As Heaney defined it in an interview in the Guardian (2 November 1974), "it's almost a racist term, a label for a set of cultural suppositions." In fact, during his first years as a lecturer at Queen's (1968), the situation in Northern Ireland became dangerous and tense, as the civil rights movement among Catholics gathered momentum and was met with fierce opposition from Protestant Loyalists. And this desire "to drive away ghosts from the past, to set the darkness echoing and the revelation of the self to the self," can be interpreted not simply as "lyrical evocations of loss" but also as portraits of the author's state of mind.

On the other hand, the language of Tony Harrison's The School of Eloquence is, for Jonathan Barker that of "a man speaking to men." The world is "his native Leeds and the oral culture of his bookless, straight-speaking home community seen with a toughminded objectivity, in which affection is expressed through relationship or, more indirectly, through situations described" (50), as in "Study":"

Best clock. Best carpet. Best three chairs.

For deaths, for Christmasses, a houseless aunt, for those too old or sick to manage stairs.

I try to whistle in it but I can't. (S,241) 
The whole sequence is about his own class and its cultural predicament, and as Ken Worpole states, they are "obsessively worked over again and again" (63), since the same traumatic moments occur, for instance, his relatives' deaths and funerals:

Uncle Joe came here to die. His gaping jaws once plugged in to the power of his stammer patterned the stuck plosive without pause like a d-d-damascener's hammer. $(\mathrm{S}, 242)$

According to Nicholas McGuinn, by the time the poems in Death of a Naturalist were written, Seamus Heaney had come to understand "the reason for that moment of early sorrow." Like Blake and Wordsworth and other poets before them, he is grieving, in this first volume, for what he has called the fall into manhood. Try as he might to defend that secret nest of childhood, his small imperfect limits would keep breaking" (15), just as he recalls while rebuilding "The Barn"10 of his home:

Threshed corn lay piled like grit of ivory

Or solid as cement in two-lugged sacks. (TB,344)

"I wrote about childhood because I couldn't help it," affirmed Heaney in The Listener (661), and in his first book of verse, Death of a Naturalist, he was performing a duty and freeing himself of a burden. His aim, according to McGuinn, is not so much "to analyse those childhood experiences of loss," but "to relive them, pay homage to them, and then let them go" (15-18).

In "The Barn," Seamus Heaney portrays the dark underside of childhood. The opening stanzas acclimatize us to a highly figurative perception of the barn, where the exotic mingles with the sinister:

The musty dark hoarded an armoury

Of farmyard implements, harness, plough-stocks. (TB,344)

Like this poem, the intimate commemorative family poems of School of Eloquence, by Tony Harrison try to show the sequence of memories to childhood, as we can see in "Long Distance II":"

Though my mother was already two years dead

Dad kept her slippers warming by the gas,

put hot water bottles her side of the bed

and still went to renew her transport pass. (LD,242)

When Harrison's father appears in the poem, he is a real person, presented to the reader with the ambivalence felt by many sons for their fathers. The sequence is remarkable in its ability to deal with a wide range of powerful primary emotions, similar 
to Greek drama: "You couldn't drop in. You had to phone" (LD,242). And his father is cast as a figure of tragi-comedy:

He'd put you off an hour to give him time

to clear away her things and look alone

as though his still raw love were such a crime. (LD,242)

Though in principle committed to an open-ended structure, capable of infinite extension, Harrison has gradually evolved a clear, thematic, tripartite frame for his sequence:

He couldn't risk my blight of disbelief

though sure that very soon he'd hear her key

scrape in the rusted lock and end his grief. (LD,242)

The sequence works for the reader because Harrison never slips into sentimentality, and is intellectually and emotionally honest throughout: "He knew she'd just popped out to get the tea." (LD,242) In fact, Tony Harrison's poems reveal an actual, uncomfortable and real world, in which things are unresolved, as happens in life: "I believe life ends with death, and that is all" (LD,242). And he ends the section with an image of himself, at his writing-desk, reflected in the glass of a photo-frame of his dead parents:

You haven't both gone shopping; just the same, in my new black leather phone book there's your name and the disconnected number I still call. (LD,242)

On the other hand, for Seamus Heaney, according to Catherine Byron, "there is a sense in which exile, whether chosen or imposed, cuts one adrift from a ghost-life of continuation in one's first country." (246) Heaney's need for a sense of place to sustain his poetic talent traps him in a vicious circle. By choosing poetry instead of farming, he distances himself from his family; he loses touch with the source of his poetic inspiration, the act of creation becoming an act of destruction. Thus, in this early poem it is possible to see an effort to create what Elmer Andrews calls a visionary power, an order of perception beyond normal seeing and hearing: "This poem contains in germinal form -before the solitary state of fear, that is both positive and intense, grows into wonderHeaney's early intuition of the world's mystery" (24). And in response to the dark and to fear the poet's mind grows:

There were no windows, just two narrow shafts

Of gilded motes, crossing, from air-holes slit

High in each gable. (TB,344)

In the same way, Tony Harrison's poems about his parents are more than simple elegies, and to praise them for being moving, as most reviewers and critics have done, is "to emasculate them of their hard political edge" (Morrison 55). In "Clearing I", ${ }^{12}$ Harrison enumerates: 
The ambulance, the hearse, the auctioneers clear all the life of that loved house away. The hard-earned treasures of some 50 years sized up as junk, and shifted in a day. $(C, 243)$

While in "The Barn," as Andrews (23) suggests, imagination works "not to contain or conquer what is chaotic or frightening, but to exacerbate such experiences," the natural world fills the child with dread and loathing, not because of its "intrinsic qualities," but because of "what the child's imagination makes of it." Like Hughes, Heaney opposes "the idealised, genteel picture of nature by emphasizing its predatory, terrifying aspect." This poem gives the readers a sense of familiarity to identify themselves with the action:

The one door meant no draughts

All summer when the zinc burned like an oven. (TB,344)

Perception is creative in the dark, womb-like interior which the poet explores:

Slowly bright objects formed when you went in.

Then you felt cobwebs clogging up your lungs

And scuttled fast into the sunlit yard. (TB,344)

Michael Parker (66) thinks that the Gothic menace is conveyed "through its sounds - $s, p, c, g, b, s h$ - and its imagery," and his shivers are recreated "by the references to the oppressive atmosphere inside the barn, one minute like an oven, the next a place of chilly concrete." In this space "sharp objects and frightening creatures conspired together" and scythe's edge, pitch-fork's prongs, bright-eyes explore the child's initiation into fear:

And into nights when bats were on the wing

Over the rafters of sleep, where bright eyes stared

From piles of grain in corners, fierce, unblinking.

The dark gulfed like a roof-space. (TB,344)

At the end of the poem, in the black depths, the two-lugged sacks turn into great blind rats advancing on the boy. This vision frightens the boy, who lies face-down, in order to avoid the increasing terror:

\section{I was chaff}

To be pecked up when birds shot through the air-slits.

$I$ lay face-down to shun the fear above.

The two-lugged sacks moved in like great blind rats. (TB,344)

The nightmare ends with the metamorphosis of two-lugged sacks into great blind rats -only as an adult was he able to overcome his distate for rats, whose presence reminds him that the pursuit of knowledge is not without danger in that hellish nightmare. As Michael Parker puts it, in Death of a Naturalist, the young poet "overcomes his unease at 
abandoning the slane for the pen, by affirming his kinship with the humble diggers of ancestral turf within his own family, and within Gaelic and Irish Literature." (75) And it is in "The Barn," perhaps one of the best constructed poems in this collection, that Heaney's fear turns out to be more than a simply destructive element, since, as Elmer Andrews states, "in the dark, fear is aroused because the ordinary conceptual structure of the world is deranged and different orders of being flow into one another." (24) Thus, the memories of childhood become for Heaney and Harrison their image of the self, the repossession of imaginative, linguistic, political, spiritual poetic talent.

As we have seen, in much post-Second World War literature the form links with fantasy. Writers try to reconcile form and experience, but also to attend to the nervousness and restlessness of contemporary life. That is why in their literary world the realistic contrasts with the romantic while they use imagistic methods to explore the fantastic, the surreal or the mythical, trying to describe strange, grotesque characters and to find new alternatives to those classic images which have always been present in literature.

\section{Notes}

1. From Wodwo (1967) in The Penguin Book of Modern British Short Stories, Malcolm Bradbury (ed). London: Penguin Books, 1988, 126-134. (RH)

2. From Wodwo (1967), in British Poetry Since 1945, E.Lucie-Smith (ed). London: Penguin Books, 1985, p. 147. (W)

3. From Wodwo (1967), in British Poetry Since 1945, op. cit., p. 151. (P)

4. From Watching me Watching You, in The Penguin Book of Modern British Short Stories, op. cit., pp.309-325. (We)

5. In British Poetry Since 1945, op. cit., pp. 121-122. (MB)

6. From Mum and Mr Armitage, in The Penguin Book of Modern British Short Stories, op. cit., pp.334-340. (CH)

7. From The Collected Stories of Elizabeth Bowen (1944), in The Penguin Book of Modern British Short Stories, op. cit., pp. 32-45. (MK)

8. From Bang Bang You're Dead, in The Penguin Book of Modern British Short Stories, op. cit., pp. 334-340. (HFP)

9. From The School of Eloquence, in British Poetry Since 1945, op. cit., pp. 241. (S)

10. From Death of a Naturalist 1966, in British Poetry Since 1945, op. cit., p. 344. (TB)

11. From The School of Eloquence, in British Poetry Since 1945, op. cit., pp. 242. (LD)

12. From The School of Eloquence, in British Poetry Since 1945, op. cit., pp. 244. (C) 


\section{Works Cited}

Andrews, Elmer. The Poetry of Seamus Heaney. London: The Macmillan Press Ltd, 1988.

Allen, Walter. Tradition and Dream. London, 1964.

Asley, Neil, ed. Tony Harrison. Newcastle: Bloodaxe Books Ltd, 1991.

Austin, Allan E.. Elizabeth Bowen. New York: Twayne Publishers, Inc, 1971.

Bakhtin, Michail. The Dialogic Imagination: Four Essays, ed. Michael Holquist, trans. Caryl

Emerson and Michael Holquist. Austin: University of Texas Press, 1982.

. Rabelais and His World. Trans. Hélène Iswolsky. Bloomington: Indiana University Press, 1984.

Bainbridge, Cyril. Something Happened Yesterday. London: Duckworth, 1993.

Barker, Jonathan. "Peru, Leeds, Florida, and Keats," in Asley, Neil (ed.) Tony Harrison.

Newcastle: Bloodaxe Books Ltd, 1991, 46-52.

Barnard, Robert. A Short Story of English Literature. Oxford: Blackwell, 1984.

Bold, Alan. Muriel Spark: An Odd Capacity for Vision. London/Totowa,NJ: Vision, Barnes \& Noble, 1984.

Bradbury. Malcolm, ed. The Penguin Book of Modern British Short Stories. London: Penguin Books, 1988.

Burris, Sidney. The Poetry of Resistance: Seamus Heaney and the Pastoral Tradition. Athens:

Ohio University Press, 1990.

Byron, Catherine. Out of Step: Pursuing Seamus Heaney to Purgatory. Bristol: Loxwood Stoneleight, 1992.

Cadogan, Mary \& Patricia Craig. Women and Children First: The Fiction of Two World Wars.

London: Gollancz, 1978, 279-281.

Corcoran, Neil. Seamus Heaney. London: Faber and Faber Limited, 1986.

Doyle, Brian. English and Englishness. London and New York: Routledge, 1989.

Dunn, Douglas "Formal Strategies in Ted Hughes's Poetry," in Asley, Neil, ed. Tony Harrison.

Newcastle: Bloodaxe Books Ltd. 1991, 129-32.

Faas, Ekbert. Ted Hughes: The Unaccommodated Universe. Santa Barbara, CA: Black Sparrow Press, 1980.

Forrest-Thomson, Veronica. Poetic Artifice. Manchester: Manchester University Press, 1978.

Gifford, Terry \& Neil Roberts. Ted Hughes: A Critical Study. London: Faber and Faber, 1981.

Handwerk, Gary. Irony and Ethics in Narrative: From Schlegel to Lacan. New Haven: Yale University Press, 1985.

Hartley, George. "Nothing To Be Said," in Thwaite, A. ed. Larkin at Sixty. London: Faber \& Faber Limited, 1982, 87-97. , ed. Philip Larkin (1922-1985): A Tribute. London: The Marvell Press, 1988.

Hassan, Salem K.. Philip Larkin and his Contemporaries. An Air of Authenticity. London: Macmillan Press, 1988.

Hirschberg, Stuart. Myth in the Poetry of Ted Hughes. Dublin: Wolfhound Press, 1981.

Hobsbaum, Philip (1964) "Where Are the War Poets?," Outposts, vol. 61, pp. 20-24.

Hughes, Ted. Poetry in the Making. London: Faber and Faber, 1967.

Hynes, Joseph. "Muriel Spark and the Oxymoronic Vision," Contemporary British Women

Writers: Narrative Strategies. New York: St. Martin's, 1983, pp. 161-87.

Johnston, John H.. The Poet and the City. Athens: The University of Georgia Press, 1984.

Leavis, Q.D.. Collected Essays. Volume I. The Englishness of the English Novel. Cambridge University Press. 
Leech, Geoffrey N, 1983. A Linguistic Guide to English Poetry. London.

Lucas, John. England and Englishness. London: The Hogarth Press, 1990.

McGuinn, Nicholas. Seamus Heaney: A Student's Guide to the Selected Poems 1965-75. Oxford:

Arnold-Wheaton, 1986.

Miller, Karl (1974) “A Novelist Worth Knowing,” New York Review of Books 16 May, pp. 25-28.

Morrison, Blake "The Filial Art," in Asley, Neil ed. Tony Harrison. Newcastle: Bloodaxe Books

Ltd., 1991, pp. 54-60.

Motion, Andrew. Philip Larkin. London: Methuen, 1982.

Philip Larkin: A Writer's Life. London: Faber \& Faber, 1993.

O'Neill, Michael. "Larkin's The Whitsun Weddings: The Importance of Difference," in Harley

(ed.) Philip Larkin (1922-1985): A Tribute. London: The Marvell Press, 1983, 184-197.

Parker, Michael. Seamus Heaney: The Making of the Poet. London: Macmillan, 1993.

Porter, David. "Beasts/Shamans/Baskin: The Contemporary Aesthetics of Ted Hughes," in Scigaj,

Leonard M. (ed.) Critical Essays on Ted Hughes. NY: G.K.Hall \& Co., 1992, 49-66.

Punter, David. The Hidden Script: Writing and the Unconscious. London: Routledge \& Kegan Paul, 1985.

Randisi, Jennifer Lynn. On Her Way Rejoicing: The Fiction of Muriel Spark. Washington,

D.C.:Catholic University of America Press, 1991.

Richmond, Velma Bourgeois. Muriel Spark. New York: Ungar, 1985.

Ricks, Christopher. "Like Something Almost Being Said," in Thwaite,A. ed., 120-30.

Riffaterre, Michael. Semiotics of Poetry. Bloomington: Indiana University Press, 1978.

Rossen, Janice. Philip Larkin: His Life's Work. London: Harvester Wheatsheaf, 1989.

Robinson, Craig. Ted Hughes as Shepherd of Being. London: Macmillan, 1989.

Sagar, Keith. Ted Hughes. Essex: Longman Group Ltd, 1972.

. The Art of Ted Hughes. Cambridge: Cambridge Univ. Press., 1975.

. "The Poetry does not Matter," in Scigaj, Leonard M. (ed.) Critical Essays on Ted Hughes.

NY: G.K.Hall \& Co., 1992, pp. 9-108.

Sage, Lorna. "Female Fictions: The Women Novelists," The Contemporary English Novel, ed.

Malcolm Bradbury and David Palmer, Stratford-upon-Avon Studies 18. London: Arnold,

$1979,80-87$.

Scigaj, Leonard M. The Poetry of Ted Hughes: Form and Imagination. Iowa: University of lowa

Press, 1986.

(ed.) Critical Essays on Ted Hughes. NY: G.K.Hall \& Co, 1992.

Smith, E. Lucie. British Poetry Since 1945. London: Penguin Books, 1985.

Smith, Stan. "Wolf Masks: The Early Poetry of Ted Hughes," in Scigaj, Leonard M., ed. Critical Essays on Ted Hughes. NY: G.K.Hall \& Co., 1992, 67-8.

Spiering, M.. Englishness. Foreigners and Images of National Identity in Postwar Literature.

Amsterdam: Rodopi, 1992.

Sukenick, Ronald. "The Death of the Novel," The Death of the Novel and Other Stories. New

York: Dial, 1969, 38-42.

Thwaite, Anthony, ed. Larkin at Sixty. London: Faber \& Faber Limited, 1982.

Timms, David. Philip Larkin. Edinburgh: Oliver \& Boyd, 1973.

Valverde, Gloria. "A Textual Study of Beryl Bainbridge's Another Part of the Wood and Weekend with Claude," 2 vols., diss., Texas Tech U, 1985.

Walder, Dennis. Ted Hughes. Milton Keynes: Open University Press, 1984.

Warner, Val. "Beryl Bainbridge," Contemporary Novelists, ed. James Vinson and D.L. Kirkpatrick. London: St. Martin's, 1976, 79-80. 
Wennö, Elisabeth. Ironic Formula in the Novels of Beryl Bainbridge. Göteborg, Sweden: Acta Universitatis Gothoburgenis, 1993.

West, Thomas. Ted Hughes. London \& NY: Methuen, 1985.

Williams, Raymond. The Country and the City in the Modern Novel. London: Hogarth, 1987 (1985).

Whittaker, Ruth. Muriel Spark. London: Lorrimer, 1982.

Worpole, Ken. "Scholarship Boy: The Poetry of Tony Harrison" in Asley, Neil (ed.) Tony Harrison. Newcastle: Bloodaxe Books Ltd., 1991, 61-74.

Yakovleva, Valentina (1984) "On Reading Beryl Bainbridge: A Voice from the Public," Soviet Literature 11. 440, 141-149. 